（375） アビェチン酸とプロピレンオキサイド及びェチレンオキサイド との反応生成物について

\author{
黄慶雲・岸田利 郎・井本稔
}

\section{1. 緒言}

非イオン系活性剤は将来性のある型として数多く研究されてい る。我々は親水基としてポリオキシェチレン文はポリオキシプロ ピレンを用い，蹯水基として従来から起泡肪やロジン石踰として 知られているアビェチン酸を用い，非イオン活性剤の合成を行つ た。

最初常圧又は溶媒添加の下でこれを試みたが，良好な結果を得 るには到らなかつた。それ故加圧下で合成を行つた結果，好収量 で目的物を得た。
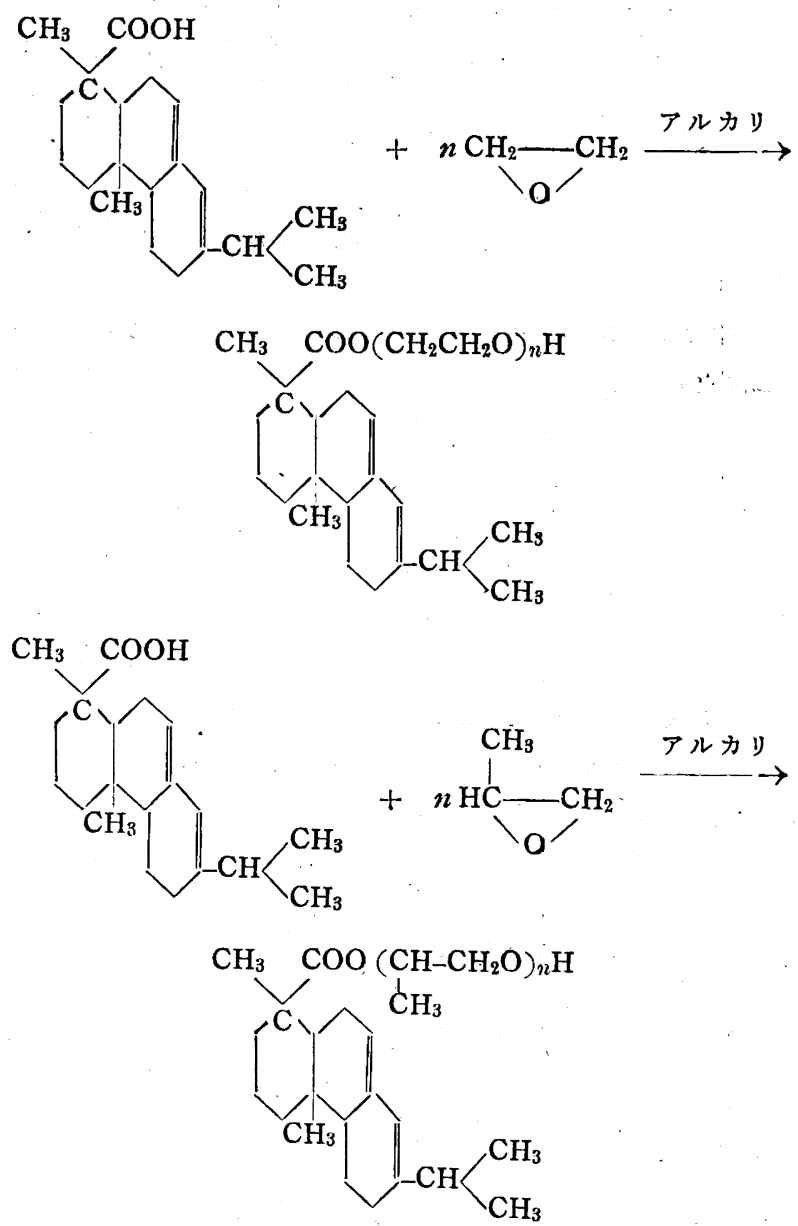

エチレンオキサイドは附加物に異性体を生じないが，プロピレ ンオキサイドについてはメチル基の位置によつて当然二つの異性 体が考えられる。オキサイドが石炭酸か文はアルコールと附加寸 る際, 酸性触媒の場合1) 第 1 級アルコールエーテルと第 2 級アル コールェーテルの混合物がほぼ等量生成するが, アルカリ性触

1) Sexton, Briton, J. Am. Chem. Soc, 70, 3606 (1948).
媒 $1,2,3,4,5)$ では殆ど第 2 級アルコールエーテルのみが得られると 報告している。この反応は葫性カリ触媒を用いた故第 2 級アルコ ールエーテルの構造を形成すると考えられる。

又これ等のアビェチン酸エステルの表面張力の性状を測定し， 表面活性剂として良好な結果を得た。正確なデータは取れなかつ たが，乳化性，起泡性も可成り良好に思えた。

\section{2. 実 験 試 料}

1）アビエチン酸はロジンを減圧蒸溜し,沸点 $245 \sim 270^{\circ} \mathrm{C} / 9.5$ $\mathrm{mm}$ の溜分 (酸価 174.7 176.4，アビエチン酸の含有率 $94.5 \sim$ 95.4\%)を实唭試料とした。

2）プロピレンオキサイドは，宇部興産株式会社堂素工場に於 ける低温乾溜ガス中より得たプロピレンガスより合成したものを 蒸溜して沸点 $35 \sim 40^{\circ} \mathrm{C}$ の溜分を用いた。

3）エチレンオキサイドは冷却管と分液ロウト及改びガスの出口 を附せる三つロフラスコにェチレンクロルヒドリンの $40 \%$ 水溶

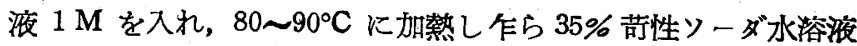
を滴下し，発生するエチンンオキサイドをソーダ石灰乾燥荅に通 じて乾燥し, 氷冷せる捕集管に捕集寸る。沸点 $11 \sim 13^{\circ} \mathrm{C}$, 収量 約 $70 \%$ 。

\section{3. 実験結果並に考察}

ポリエチレン（邓はプロピレン）グリコールアビエチン酸エス テルの合成 肉厚硬質試験管 (内容的 $150 \mathrm{cc}$ ) 中に所要量のアピ エチン祖とエチレンオキサイド（双はプロピレンオキサイド）と 何れ女同量 $(0.5 \mathrm{~g})$ の熔融苛性カリを触媒とし, 試験管を氷冷下 で仕込み，水冷下で封管を行5。これを誼浴で 6〜11 時間 120 $\sim 150^{\circ} \mathrm{C}$ で加熱反応せしめると内容物は漸次粘度を増し色調が濃 褐色になる。反応後生成物をベンゾール 50〜100 cc に溶解せし め, $5 \%$ の苛性ソーダ水浴液を静かに数回（毎回 $20 \mathrm{cc}$ ) 加之, 未 反忘のアビエチン酸と大部分の触媒苛性カリを洗佟除去し，次て 少量の水を静かに加えて洗條する。精製されたポリアビエチン酸 エステルのベンゾール溶液は子めベンゾールを溜去した後, 110 $\sim 120^{\circ} \mathrm{C} / 10 \mathrm{~mm}$ で 1 時間減圧乾燥すると中性の赤褶色粘程な生 成物を得る。以下の附加物もずべてこの方法で精製を行つた。生 成物の平均分子量はベンゾールの氷点降下法により各 3 回湘定し た平均值である。実験結果を綜合して第 1 表に示す。

この結果を要約すると，1）エチレンオキサイドの附加生成物 は茶褐色乃至濃褐色を呈し，附加数が大きくなるにつれて色調が

2) Hard, Perletz, J. Am. Chem. Soc. 68, 38 (1946).

3) Chitwood, Freure, ibid. 68, 680 (1946).

4) Swern, Billen, Knight, ibid. 71, 1152 (1949).

5) Cyruso, Guss, ibid. 71,3460 (1949). 
第 1 表 ポリエチレン（又はプロピレン）グリコールアビエチン酸エステルの合成

\begin{tabular}{|c|c|c|c|c|c|c|c|c|}
\hline $\begin{array}{l}\text { 実験 } \\
\text { 番号 }\end{array}$ & $\begin{array}{l}\text { アビェチン䣫 } \\
(\mathbf{g})(\mathbf{M})\end{array}$ & $\begin{array}{l}\text { オキサイド } \\
(\mathrm{g})(\mathrm{M})\end{array}$ & モル比 & $\begin{array}{c}\text { 反応温度 } \\
\left({ }^{\circ} \mathrm{C}\right)\end{array}$ & $\begin{array}{l}\text { 反成㭙間 } \\
\text { (hr) }\end{array}$ & $\begin{array}{l}\text { 収 率 } \\
(\%)\end{array}$ & $\begin{array}{l}\text { 平均 } \\
\text { 分子量 }\end{array}$ & $\begin{array}{l}\text { 附加数 } \\
(\boldsymbol{n})\end{array}$ \\
\hline $\mathbf{E}_{1}$ & $9.1(0.03)$ & $6.6(0.15)$ & 5 & $120 \sim 130$ & 6 & 89 & 495 & 4.3 \\
\hline $\mathbf{E}_{2}-$ & $+\quad 1$ & $9.3(0.21)$ & 7 & "I & $" \prime$ & 86 & 523 & 5.0 \\
\hline $\mathbf{E}_{3}$ & $" \prime$ & $13.2(0.30)$ & 10 & $130 \sim 140$ & $" \prime$ & 92 & 699 & 7.2 \\
\hline $\mathbf{E}_{\mathbf{6}}$ & $" \prime$ & $17.2(0.39)$ & 13 & "I & $" 1$ & $" \prime$ & 760 & 10.4 \\
\hline $\mathbf{E}_{7}$ & $4.3(0.014)$ & II & 21 & 11 & $" 1$ & 89 & 962 & 15.0 \\
\hline $\mathbf{E}_{8}$ & $3.0(0.01)$. & $" \prime$ & 30 & "I & $" \prime$ & 80 & 1016 & 16.2 \\
\hline $\mathbf{P}_{\mathbf{1}}$ & $9.1(0.03)$ & $12.1(0.21)$ & 7 & $130 \sim 140$ & 6 & $" \prime$ & 570 & 4.6 \\
\hline$P_{2}$ & "I & $17.4(0.30)$ & 10 & 11 & $" 1$ & 88 & 558 & 4.4 \\
\hline $\mathbf{P}_{7}$ & $3.0(0.010)$ & $" \prime$ & 30 & $\cdot 130 \sim 150$ & 8 & 93 & 569 & 4.6 \\
\hline
\end{tabular}

薄くなつてくると共に, 粘稩な液体から半固体を経て固体状に変 つてゆく。エチンンオキサイドの附加数 $n=12$ 位迄は螢光を有 し，これ以上になると殆ど固体状で，螢光を呈しない。収量と平 均分子量よりエキレンオキサイドの反応モル数が大きくなると何 れの場合る予想される附加数よりも小さく，或る程度自己重合し ていると考えられる。2) プロピレンオキサイドの附加生成物は 何れも黄褐色乃至赤褐色の螢光性の粘稠な液体でモル数が大きく なるにつれて赫色から黄褐色へと色が焱くなると共に，粘度が 幾分か低下してくる。平均分子量から，プロピレンオキサイドの 附加数は殆ど 4.5 前後である故, 残りの大部分は自己重合に消費 したものと考えられる。大河原氏日) はプロピレンオキサイドとア ビエチン酸をオートクレーブで同じくアルカリ触媒を用いて附加 数 $n=9.6$ の物質を得ているが，我々は第 1 表の如き附加数 $n=$ 4.5 しか得られなかつた。3）エチレンオキサイド改びプロピレ ンオキサイドとアビェチン酸との附加重合物は何れるェーテル, ベンゾール, エタノール,アセトン, 酘酸エチル等の有機溶媒に 易溶で，水に対しては附加数 (n) が大きい程溶解度が大きくな る。

\section{4. 衰 面 張 力}

今迄フビエチン酸の性質を利用して非イオン活性剤を合成する

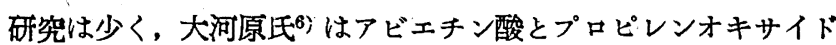
を附加重合させ，プロピレンオキサイドの附加数 $n=9.6$ のもの のみを合成し，その表面張力を測定している。又米国特許7) では エチレンオキサイドと附加重合させているが，それ等についての 正確な表面張力の測定報文がない。

我々は上に合成した各試料の水溶液について $30^{\circ} \mathrm{C}$ に於ける表 面張力を Traube の滴数計を用いて種々の濃度につき湘定した。 単位は dyne/cm である。

A. ボリエチレングリコールアビェチン酸エステルの表面張 カと濃度との関係 各種合成物てついてのモル比, 附加数及び水 溶液の表面㖘力と色調外観は第 2 表の如くである。附加数 $n=10$ 位迄は水に完全に溶解せず，何れも乳白色乃至白色の乳化液状を 呈しているが, $n=10$ 以上になると完全に溶解して薄乳白色乃至 淡黄色の透明な溶液となる。大体 $0.1 \%$ 前後の水溶液濃度で限界 濃度に達する事が判る。

エチレンオキサイド附加物の各襄度以於ける附加数と表面张力 の関䋆を第 1 図儿示す。各種附方重合物の $0.05 \%$ の水溶液では 最小の表面張力を示すには到らないが, ‘0.1\% 以上の濃度になる と最小表面层力 $38.5 \mathrm{dyne} / \mathrm{cm}$ を示す。又エチレンオキサイドの 附加数 $n=11 \sim 14$ の範囲で表面張皌が最小になり附加数 $n=15$ 以上になると逆に表面張力が上昇する。

第 2 表 ポリエチレングリコールアビェチン酸エステルの表面張力

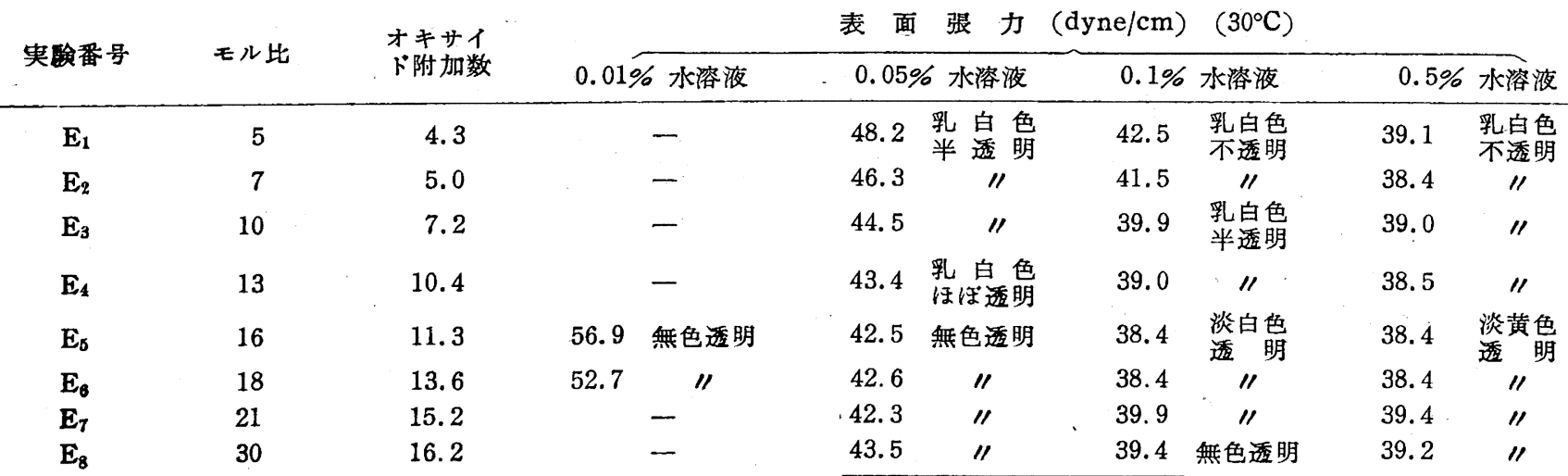

6) 大河原，工化 55, 273 (1952).

7) U.S.P. 2,519,780, Aug. 22 (1950). 
第1四 ポリエチレングリコールアビエチン酸

エステルの表面偯力と附加数との関係

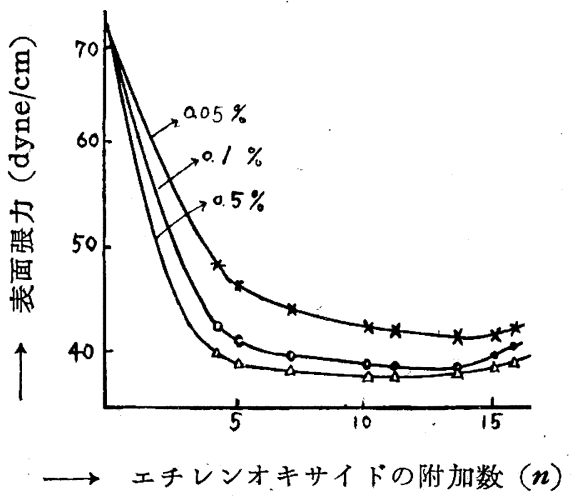

B. ボリプロピレングリコールアビェチン酸エス テルの表面 張力と濃度との関係 プロピレンオキサイドの附加数は $n=4.4$ ４.7 でこれ以上のものが得られない為, 水に対する溶解度が比 較的に悪く $P_{1}, P_{2}$ は $0.05 \%, P_{3} \sim P_{7}$ は $0.1 \%$ 迄で, それ以 上の溶解度を得る事は困難で，表面張力から見て良好な表面活性 郕とは云い難い。これ等はいずれも大体 $0.1 \%$ 前後で限界濃度汇 達する様である。これ等の関係を第 3 表炕示す。

なお，上記の二，三のポリエチレングリコールアビェチン酸エ ステルの硫酸エステルを合成し, その各種水溶液に於ける表面張 カを測定したが余り良好な結果が得られなかつた。
第3表 ポリプロピレングリコールアビエチン

酸エステルの表面張力

\begin{tabular}{|c|c|c|c|c|c|}
\hline \multirow{2}{*}{$\begin{array}{l}\text { 実験 } \\
\text { 番号 }\end{array}$} & \multirow{2}{*}{ モル比 } & \multirow{2}{*}{$\begin{array}{l}\text { オキサ } \\
\text { イド附 } \\
\text { 加数 }\end{array}$} & \multicolumn{2}{|c|}{ 表面張力（dyne/cm） } & \multirow{2}{*}{$\frac{\left(30^{\circ} \mathrm{C}\right)}{0.1 \%}$} \\
\hline & & & $0.01 \%$ & $0.05 \%$ & \\
\hline $\mathbf{P}_{1}$ & 7 & 4.6 & 64.4 & 59.2 & - \\
\hline $\mathbf{P}_{2}$ & 10 & 4.4 & 63.7 & 58.4 & - \\
\hline $\mathbf{P}_{\mathbf{3}}$ & 13 & 4.5 & 61.4 & 58.1 & 52.2 \\
\hline $\mathrm{P}_{4}$ & 16 & " & 60.8 & 54.4 & 50.8 \\
\hline $\mathrm{P}_{\boldsymbol{b}}$ & 19 & 4.6 & 60.5 & 53.7 & 50.7 \\
\hline$P_{\theta}$ & 22 & 4.7 & 60.3 & 52.8 & "I \\
\hline$P_{7}$ & 30 & 4.6 & 57.6 & " & $" \prime$ \\
\hline
\end{tabular}

1. エチレンオキサイドとアビエチン酸との附加重合はオキサ イドの使用モル比とともに附加数 $(n)$ が大きくなる。

2. エチレンオキサイドの附加数 $n=11 \sim 14$ で $0.1 \%$ 以上の 水溶液の時に最小の表面張力 $38.4 \mathrm{dyne} / \mathrm{cm}$ を示し, 非イオン活 性偊として使用に供し得ると考えられる。

3. プロピレンオキサイドとアビエチン酸との附加重合はオキ サイドのモル比に関係なく附加数が一定で $n=4.4 〜 4.7$ である。

4. プロピレンオキサイドの附加数は $n=4.4 \sim 4.7$ で一定な るため水溶性が悪く, 又表面張才うが大きいので活性成として使用 に供し得ない。

（昭和 28 年 4 月 2 日, 日化第 6 年会講演）

（横浜国立大学工学部電気化学科：横浜市南区）（昭和 28 年 5 月 23 日受理）

\title{
（376）檢知管によるカス分析法の研究（第10 報）
}

\section{正ヘキサン蒸気の迅速定量法}

\author{
小林 義 隆・北川徹三
}

\section{1. 緒 言}

抽出剤に正へキサンを使用している化学工場は最近増加してい るが，この蒸気は引火文は爆発を㶐き起し易く空気中に於ける爆 発下限界の測定(値1)は $1.25 \%$ である。文一種の有害蒸気であつ て米国座業衛生協会に於ては 0.05\%をその恕限量2) と定めてい る。従つて防災改び学衝衛生上, そのほか溶刜回収率の増加上か らも当然へキサン蒸気の迅速定量法が要求せられる。しかるに彷 来, この目的に適した定量法は殆ど見当らなかつたので，著者等 は検知管による正へキサン蒸気の分析法について研究を行い，簡 易, 迅速に，乙か子比較的精度よく測定できる好結果を得たので 以下にその大要を述ベる。

\section{2. 実験}

\section{(1) 分析装圈及び測定操作法}

(A) 正へキサン検知管：先ず㭘知剤について検討を行つた。

1) B. Lewis and G. von Elbe, Combustion, Flames and Explosions of Gases 389 (1938).

2) Arch. Ind. Hyg. \& Occ. Med. 4, 398 (1951).

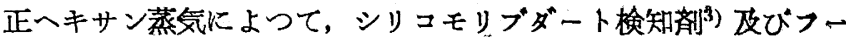
ラマイト検知荗）は鋭敏な着色を示す。即ち前者はモリブデン青 を生じ, 後者は構造不明の青色化合物を生じ何れも青変するが, 著者等によつて得られたク口ム硫酸㭘知剂は上述の検知猟に比し

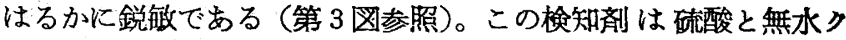
ロム酸との混合液を 60 80 メッシュのシリカゲル粒に吸着させ て乾燥したもので登黄色を呈しているが，還元性ガスによつて 6 価の Cr が還元されるため黒緑色に着色する。検知管は上述の検 知剤の $0.20 \mathrm{~g}$ を内径 $2 \mathrm{~mm}$ 内外の細いガラス管に充填し，その 充填層の長さ $L$ を 60 80 mm におさめたものである。検知斉 の両端は少量のガラス粒をへだてて綿栓で固定し，ガラス管の両 端は熔封して保存性を保たせた。

（B） ガス採取器： ガス採取器としては内容積 $30 \mathrm{cc}$ のガラ ス製注射筒を採用した。

(C) 測定操作法 : 試料空気 $30 \mathrm{cc}$ をガス採取器を用いて検

3) Schepherd, Ind. Eng. Chem. Anal. Ed. 19,7? (1947).

4) Lamb, Bray and Frazer, Ind. Eng. Chem. 12, 213 (1920) ; Hoover, ibid. 13, 770 (1921). 